\title{
THE EFFECTIVENESS OF HEALTH PROMOTION ON INCREASING THE KNOWLEDGE OF COVID-19 AMONG ISLAMIC HIGH SCHOOL STUDENTS IN DEPOK, WEST JAVA
}

\author{
Yanti Harjono Hadiwiardjo, Sri Wahyuningsih, Pritha Maya Savitri \\ Department of Community Medicine, Faculty of Medicine, Universitas Pembangunan Nasional \\ "Veteran" Jakarta
}

\begin{abstract}
Background: After undergoing a large-scale social distancing period of 5 months, and considering learning needs, the Ministry of Education and Culture decided to carry out face-to-face learning for schools in the green and yellow zones by implementing strict health protocols. Students, teachers, administrative staff, and workers need to have knowledge about Covid-19. The purpose of this study was to determine the level of knowledge of Dian Didaktika Islamic high school students regarding Covid-19 before and after being given health promotion in preparation for face-to-face learning.

Subjects and Method: This was a cross-sectional study conducted at Dian Didaktika Islamic high school, Jakarta. All high school students of class X, XI and XII totaling 164 people were enrolled in this study. The independent variable was health promotion using powerpoints and the dependent variable in this study was the level of knowledge. The level of knowledge was measured using questionnaire and analyzed using Wilcoxon test.

Results: The majority of students were 16 years old (47.0\%), male. (54.9\%), and from class X students (58.5\%). The level of knowledge on Covid-19 was increased after being given health education (Mean= 77.48) than before being given education (Mean= 72.88), and they were statistically significant $(\mathrm{p}=0.001)$.

Conclusion: Health promotion can increase knowledge about Covid-19 among high school students.
\end{abstract}

Keywords: Covid-19, students, knowledge, health promotion

Correspondence:

Yanti Harjono Hadiwiardjo. Department of Community Medicine, Faculty of Medicine, Universitas Pembangunan Nasional "Veteran” Jakarta. Email: yantiharjono@upnvj.ac.id, Telp: 082124018795 